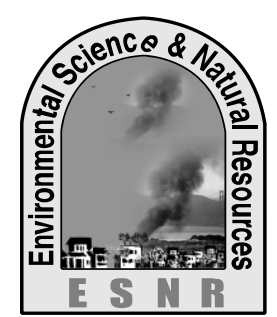

\title{
Use of Botanicals as Environmentally Safe Management for Cotton Jassid
}

\author{
T. A. Siddiqua ${ }^{1}$, M. R. U. Miah ${ }^{1}$, M. R. $\operatorname{Amin}^{1}$ and K. Yesmin ${ }^{2 *}$ \\ ${ }^{1}$ Department of Entomology, Bangabandhu Sheikh Mujibur Rahman Agricultural University, \\ Gazipur, \\ ${ }^{2}$ Cotton Development Board, Mymensingh Zone \\ *Corresponding author: khaleda78cdb@yahoo.com
}

\begin{abstract}
This study evaluated the efficacy of nine botanicals against cotton jassid on cotton variety CB 12 . The nine botanical treatments were neem leaf extract@ $100 \mathrm{ml} \mathrm{L}^{-1}$ of water, turmeric powder @ $20 \mathrm{~g} \mathrm{~L}^{-1}$ of water, coriander powder @ $20 \mathrm{~g} \mathrm{~L}^{-1}$ of water, black pepper powder @ $20 \mathrm{~g} \mathrm{~L}^{-1}$ of water, chili powder @ $20 \mathrm{~g} \mathrm{~L}^{-1}$ of water, Garlic extract @ $100 \mathrm{~g}$ of grated and crushed garlic cloves per L of water, eucalyptus oil @ $5 \mathrm{ml} \mathrm{L}^{-1}$ of water, mahogany oil @ $5 \mathrm{ml} \mathrm{L}^{-1}$ of water, neem oil @ $5 \mathrm{ml} \mathrm{L}^{-1}$ of water. The botanicals were applied four times at 7 days interval during the cotton growing season. Among the tested botanicals neem leaf extract with $100 \mathrm{ml} \mathrm{L}^{-1}$ water and chili powder $20 \mathrm{~g} \mathrm{~L}^{-1}$ water after 24,48 and 72 hours of application exerted the lowest jassid population. The botanical treatments have insignificant effect on the population of beneficials. The neem leaf extract with $100 \mathrm{ml} \mathrm{L}^{-1}$ water and neem oil with 5 $\mathrm{ml} \mathrm{L}^{-1}$ water had greater effect on cotton jassid and revealed significantly lower levels of leaf infestation by number. Plots treated with neem leaf extract with $100 \mathrm{ml} \mathrm{L}^{-1}$ water and chili powder with $20 \mathrm{gL}$ water resulted in significantly higher yield than that of the control.
\end{abstract}

Key words: Botanicals, Cotton plant, Eco-friendly, Jassid and Plant products

\section{Introduction}

Cotton is one of the important cash crops in Bangladesh. It is the main raw material of textile industry. Around $4-5 \%$ of the national requirement is fulfilled through the local production, remaining 95$96 \%$ is fulfilled by importing raw cotton from the USA (40\%), Commonwealth of Independent States (35\%), Australia, Pakistan, South Africa and other cotton producing countries (25\%) (BTMA, 2010). The highest domestic cotton production was 152,534 bales in 201415 and total harvested area was 42,700 ha. (CDB, 2015).

The yield of cotton in Bangladesh is lower than that of many other cotton growing countries in the world. Insect pest infestation is one of the most important causes for the low yield of cotton in Bangladesh. The sub-tropical climate in Bangladesh resulted severe pest infestation and the crop is subject to damage by 162 species of insects those are generally categorized into sucking and chewing pests (Amin et al., 2008). There are many insect pest of American cotton in Bangladesh of which important insect pests include the chewing insect namely American bollworm, spotted bollworm and pink bollworms and the sucking insects namely the jassids, aphids and whitefly. The insect pest complex on Hill cotton is similar to American cotton. Jassids are reported to cause 19 percent reduction in cotton yield (Ali, 1992).

Amrasca biguttula Ishida known as cotton leafhopper or cotton jassid belongs to the family Cicadellidae (Order Homoptera) and is a major pest of cotton; it is possibly the most important cotton pest in Bangladesh. It has a wide range of cultivated host-plants. Jassid suck sap from tender plant parts, sometimes causing the edge of the leaves to curl downwards. Cotton jassid damage alone may reduce yield by $50 \%$, and damage by jassids and bollwoms together may reduce yield by as much as $70 \%$ (Wadud and Moniruzzaman, 2001).
Various control strategies have been adopted against cotton jassid. One common method is the use of synthetic insecticides, which can be environmentally disruptive and can result in the accumulation of residues in the harvested produce creating health hazards (Chinniah and Mohanasundaram, 1999). Effective plant extracts and products from different botanicals such as black pepper powder, chili powder, turmeric powder, coriander powder, neem oil, eucalyptus oil, mahogany oil, neem leaf extract, garlic extract etc. can easily be obtained by indigenous methods and can be used effectively for the management of cotton jassid. Botanical extracts or non-chemical materials (black pepper powder, chili powder, turmeric powder, coriander powder, neem oil, eucalyptus oil, mahogany oil, neem leaf extract, basil leaf extract, garlic extract etc.) are safe to apply, unique in action and can easily be processed. It has little or no effect on beneficial spiders, ladybird beetles, parasitoid wasp and predatory mites and insects (Walter, 1999).

\section{Materials and Methods}

\section{Experimental site and design}

The experiment was carried out in the experimental field of the Department of Entomology of Bangabandhu Sheikh Mujibur Rahman Agricultural University, Salna, Gazipur-1706, from July 2014 to April 2015. The experiment was laid out in a randomized complete block design (RCBD) with three replications. In experimental site total land area was $30.5 \mathrm{~m} \times 18 \mathrm{~m}$ including the border. The land was divided into 30 equal plots $(4 \mathrm{~m} \times 2.5 \mathrm{~m})$ with plot to plot distance of 0.5 $\mathrm{m}$ and block to block distance is $2.0 \mathrm{~m}$. The whole area of the experimental field was divided into three blocks and each block was again divided into 10 unit plots. The row to row and plant to plant spacing was maintained at $80 \mathrm{~cm} \times 40 \mathrm{~cm}$ respectively.

Collection and sowing of seeds

Seeds of Cotton variety CB-12 were collected from Central Cotton Research, Training and Seed 
Multiplication Farm, Sreepur, Gazipur, Bangladesh. The seeds of cotton were sown directly in the main field on 10 July, 2014. The intensive care and all necessary intercultural operations including irrigation, weeding, thinning etc. were done in proper time to obtain healthy plants. The seed germinated within 3-7 days. The field was irrigated lightly immediately after sowing. Necessary intercultural operations were done throughout the cropping season to obtain proper growth and development of the plants.

\section{Treatments}

Nine botanicals were used in this experiment such as young Neem leaf extract @ $100 \mathrm{ml} \mathrm{L}^{-1}$ of water, Turmeric powder @ $20 \mathrm{~g} \mathrm{~L}^{-1}$ of water, Coriander powder@20 g L $\mathrm{g}^{-1}$ of water, Black pepper powder @ $20 \mathrm{~g} \mathrm{~L}^{-1}$ of water, Chili powder @ $20 \mathrm{~g} \mathrm{~L}^{-1}$ of water, Garlic extract@100 g of grated and crushed garlic cloves per L of water, Eucalyptus oil @ $5 \mathrm{ml} \mathrm{L}^{-1}$ of water, Mahogany oil @ 5 ml L-1 of water, Neem oil @ $5 \mathrm{ml} \mathrm{L}{ }^{-1}$ of water. Spraying was started from the advent of infestation and it continued at 7 days interval up to optimum harvesting.

\section{Preparation and application of treatments}

Mature black pepper, chili, turmeric and coriander were dried in an oven at $65^{\circ}$ for $48 \mathrm{~h}$ to a constant weight, ground in a commercial grinding machine, and sieved to pass through a No. $18(1 \mathrm{~mm})$ mesh screen. Then 20 $\mathrm{g}$ dried powder of each material mixed with $100 \mathrm{~mL}$ of distilled water with 10 drops of $2 \%$ sodium dioctyl sulfo-succinate. The mixture was passed through a double-layer of cheesecloth and squeezed manually. The mixtures were then vacuum filtered using funnels. Young fresh leaves of neem Azadirachta indica were plucked from their parent plants. 100 grams of grated neem leaves were blended with 1 liters of water and 50 $\mathrm{ml}$ of soap (potash based soft soap that was used for washing dishes) and was mixed well. The mixture was passed through a fine cloth and squeezed manually. The solution was diluted in 5 liters of water. 100 grams of grated and crushed garlic cloves were blended with 1 liters of water and 100 grams of soap (potash based soft soap that was used for washing dishes) and mixed well, the mixture was strained through a fine cloth. The solution was diluted in 5 liters of water. Mahogany oil, Neem oil and Eucalyptus oil were collected from the producer from Shatkhira and Rajshahi and Chapainawabgonj, respectively. The nine botanicals insecticides were sprayed five times at 7 days' interval in which four botanicals powder, three botanicals oils and two botanicals extracts. Spraying was started from the advent of infestation at 28 October 2014 and continued to 27 November 2014. During the spraying of botanicals oil the spraying doses were mixed with Tween 20 which acts as surfactant @ 0.01\%. The spray mixture poured into the knapsack sprayer and sprayed covering the whole plants. The spraying was done during in the morning to avoid bright sunlight and drift caused by strong wind and adverse effect on pollinating insects.

\section{Statistical analysis}

The recorded data were compiled and tabulated for statistical analysis. Analysis of variance was done with the help of computer package STATISTIX 10 program. The mean differences of the treatments were observed by Least Significant Difference (LSD) test at 5\% level of probability for the interpretation of results.

\section{Results and Discussion}

Effect of management practices using botanicals in controlling cotton jassid in the present study showed statistically significant differences among the treatments in terms of percent leaves infestation after 24,48 and 72 hours of spraying. Mean jassid population on plant leave at 24, 48 1nd 72 hours post spraying are presented in Table 1 . The number of jassid $24 \mathrm{~h}$ after spraying varied from 22.19 to 98.33 per leaf and the results differed significantly $(\mathrm{p}<0.005)$. All the treatments revealed significantly lower jassid population than control. The lowest population of jassid was found in neem leaf extract (22.19) followed by Chilli powder (26.89), Mahogany oil (31.77) and neem oil (35.44). Coriander powder, Garlic extract and Black pepper exhibited jassid population of (41.44), (45.33) and (50.25) respectively, while highest number found in control (98.33) followed by Eucalyptus oil (59.00) and Turmeric powder (53.98). The maximum population reduction over control was found $72.22 \%$ in chili powder treated plot compared to other treatment.

The number of jassid at $48 \mathrm{~h}$ after spraying varied from 23.88 to 82.00 per leaf. All the treatments caused much reduction in jassid population than control. The lowest population of jassid was found in neem leaf extract (23.88) followed by Chilli powder (28.77), Mahogany oil (29.99) and Garlic extract (33.97). The highest was found in control (82.00) followed by Eucalyptus oil (45.77). Among all the treatments Coriander powder (37.89), Neem oil (38.77) and black pepper (40.11) also produced significant results compared to control plot. The maximum population reduction over control was found $70.36 \%$ in neem leaf extract treated plot and minimum was $43.43 \%$ in Eucalyptus oil treated plot.

The number of jassid at $72 \mathrm{~h}$ after spraying varied from 15.67 to 73.00 per leaf and the results differed significantly ( $\mathrm{p}<0.005)$. The lowest population of jassid was found in Chilli powder (15.67) followed by neem leaf extract (17.77) and Mahogany oil (20.11). The highest population was found in control (73.00) plot. The maximum population reduction over control was found $78.53 \%$ in chili powder treated plot compared to other treatments. 
Table 1. Efficacy of various plant products on cotton jassid population after 24, 48 and 72 hours of spraying

\begin{tabular}{|c|c|c|c|c|c|c|}
\hline \multirow[t]{3}{*}{ Treatments } & \multicolumn{6}{|c|}{ Jassid population with efficacy after different hours of treatments } \\
\hline & \multicolumn{2}{|c|}{$24 \mathrm{~h}$} & \multicolumn{2}{|c|}{$48 \mathrm{~h}$} & \multicolumn{2}{|c|}{$72 \mathrm{~h}$} \\
\hline & $\begin{array}{c}\text { Jassid } \\
\text { number/leaf }\end{array}$ & $\%$ Efficacy & $\begin{array}{c}\text { Jassid } \\
\text { number/leaf }\end{array}$ & $\begin{array}{c}\% \\
\text { Efficacy }\end{array}$ & $\begin{array}{c}\text { Jassid } \\
\text { number/leaf }\end{array}$ & $\%$ Efficacy \\
\hline Neem leaf extract & $22.19 \mathrm{i}$ & 77.28 & $23.88 \mathrm{f}$ & 70.36 & $17.77 \mathrm{fg}$ & 75.45 \\
\hline Turmeric powder & $53.98 \mathrm{bc}$ & 44.56 & $45.33 \mathrm{bc}$ & 44.00 & $31.00 \mathrm{bc}$ & 57.53 \\
\hline $\begin{array}{l}\text { Coriander } \\
\text { powder }\end{array}$ & 41.44 ef & 57.42 & $37.89 \mathrm{~d}$ & 53.14 & $25.44 \mathrm{~d}$ & 65.15 \\
\hline $\begin{array}{l}\text { Black pepper } \\
\text { powder }\end{array}$ & $50.25 \mathrm{~cd}$ & 48.31 & $40.11 \mathrm{bc}$ & 50.38 & $29.33 \mathrm{c}$ & 59.82 \\
\hline Chilli powder & 26.89 hi & 72.22 & 28.77 ef & 64.33 & $15.67 \mathrm{~g}$ & 78.53 \\
\hline Garlic extract & $45.33 \mathrm{de}$ & 53.35 & $33.99 \mathrm{de}$ & 57.98 & $24.33 \mathrm{~d}$ & 66.67 \\
\hline Eucalyptus oil & $59.00 \mathrm{~b}$ & 39.46 & $45.77 \mathrm{~b}$ & 43.43 & $34.11 \mathrm{~b}$ & 53.27 \\
\hline Mahogany oil & $31.77 \mathrm{gh}$ & 67.28 & 29.97 ef & 62.83 & 20.11 ef & 72.45 \\
\hline Neem oil & $35.44 \mathrm{fg}$ & 63.56 & $38.77 \mathrm{~cd}$ & 52.04 & $22.12 \mathrm{de}$ & 69.69 \\
\hline Control & $98.33 \mathrm{a}$ & - & $82.00 \mathrm{a}$ & - & $73.00 \mathrm{a}$ & - \\
\hline
\end{tabular}

Data expressed as mean. Means within a column followed by same letters are not significantly different LSD, $\mathrm{p} \leq 0.05$.

Table 2 showed the number of ant, spider and lady bird beetle which were found in pitfall traps. There were no effects on the natural enemies due to the application of various botanicals. The table showed that the number of ant among the treatments ranged from 13.33 to 14.24 and there was no significant difference $(p \leq 0.05)$. Control plot has highest number of ant (14.24) followed by coriander powder treated plot (14.16). There was insignificant difference among the treatment in the number of spider which range from 7.33 to 8 . In case of lady bird beetle, number of lady bird beetle among the treatment ranged from 7.83 to 9.08 and there was no significant difference among the treatments.

Table 2. Effect of different plant products on the population of natural enemy such as ant, spider and ladybird beetle

\begin{tabular}{lccc}
\hline Treatments & \multicolumn{3}{c}{ Name and Number of natural enemies after treatments } \\
\cline { 2 - 4 } & Ant & Spider & Ladybird beetle \\
\hline Neem leaf extract & $13.5 \mathrm{a}$ & $7.4 \mathrm{ab}$ & $7.91 \mathrm{a}$ \\
Turmeric powder & $14.08 \mathrm{a}$ & $7.8 \mathrm{ab}$ & $8.16 \mathrm{a}$ \\
Coriander powder & $14.16 \mathrm{a}$ & $7.6 \mathrm{ab}$ & $8.75 \mathrm{a}$ \\
Black pepper & $13.58 \mathrm{a}$ & $7.5 \mathrm{ab}$ & $8.33 \mathrm{a}$ \\
Chilli powder & $13.33 \mathrm{a}$ & $7.5 \mathrm{ab}$ & $8.41 \mathrm{a}$ \\
Garlic extract & $14.00 \mathrm{a}$ & $7.33 \mathrm{~b}$ & $7.83 \mathrm{a}$ \\
Eucalyptus oil & $14.00 \mathrm{a}$ & $7.8 \mathrm{ab}$ & $9.00 \mathrm{a}$ \\
Mahogany oil & $13.41 \mathrm{a}$ & $7.7 \mathrm{ab}$ & $8.66 \mathrm{a}$ \\
Neem oil & $13.66 \mathrm{a}$ & $7.4 \mathrm{ab}$ & $7.91 \mathrm{a}$ \\
Control & $14.24 \mathrm{a}$ & $8.0 \mathrm{a}$ & $9.08 \mathrm{a}$ \\
\hline
\end{tabular}

Data expressed as mean. Means within a column followed by same letters are not significantly different LSD, $\mathrm{p} \leq 0.05$.

Significant variations were observed in Table 3 among the treatments in terms of yield of seed cotton. The highest yield was recorded in the plot treated with neem leaf extract $\left(2482 \mathrm{~kg} \mathrm{ha}^{-1}\right)$ followed by chilli powder treated plot $\left(2318 \mathrm{~kg} \mathrm{ha}^{-1}\right)$, garlic extract $\left(2086 \mathrm{~kg} \mathrm{ha}^{-1}\right)$, neem oil (2231 kg ha $\left.{ }^{-1}\right)$, mahogany oil (1954 kg ha-1), black pepper $\left(1900 \mathrm{~kg} \mathrm{ha}^{-1}\right)$, coriander powder $(1843 \mathrm{~kg}$ $\left.\mathrm{ha}^{-1}\right)$, eucalyptus oil $\left(1700 \mathrm{~kg} \mathrm{ha}^{-1}\right)$, turmeric powder $\left(1716 \mathrm{~kg} \mathrm{ha}^{-1}\right)$ and the lowest yield was observed in control plot (1453 $\left.\mathrm{kg} \mathrm{ha}^{-1}\right)$ which was significantly different from all other treatment treated plots.

The yield recorded in the plot treated with neem leaf extract was statistically different from the yield of other treated plots. The yield of cotton from the chilli powder treated plot was similar to that of neem oil treated plot. Black pepper powder treated plot is similar to mahogany oil and coriander powder treated plot. Eucalyptus oil and turmeric powder treated plot were 
statistically similar to each other. Similar result was found by Kumar and Sangappa (1989), who reported that addition of neem leaf significantly increased the yield and it was effective in increasing the yield. Mandol (2008) reported that the use of neem oil can increase in yield of cotton crop.

Table 3. Yield of seed cotton obtained by management practices using different plant products against cotton jassid

\begin{tabular}{lcc}
\hline Treatments & Yield $\left(\mathbf{k g ~ h a} \mathbf{~ h}^{-\mathbf{1}}\right)$ & \% increase over control \\
\hline Neem leaf extract & $2482 \mathrm{a}$ & 70.91 \\
Turmeric powder & $1716 \mathrm{f}$ & 18.27 \\
Coriander powder & $1843 \mathrm{e}$ & 26.96 \\
Black pepper & $1900 \mathrm{de}$ & 30.85 \\
Chilli powder & $2318 \mathrm{~b}$ & 59.65 \\
Garlic extract & $2086 \mathrm{c}$ & 43.61 \\
Eucalyptus oil & $1700 \mathrm{f}$ & 17.11 \\
Mahogany oil & $1954 \mathrm{~d}$ & 34.56 \\
Neem oil & $2231 \mathrm{~b}$ & 53.74 \\
Control & $1453 \mathrm{~g}$ & -- \\
\hline
\end{tabular}

Data expressed as mean. Means within a column followed by same letters are not significantly different LSD, $\mathrm{p} \leq 0.05$.

\section{Conclusions}

In this study nine botanicals were used to control cotton jassid. As synthetic insecticides are harmful for environment, so botanicals were used as ecofriendly management practices. Botanicals were sprayed at 7 days intervals. Effect of botanicals on the population of jassids, predator and yield of cotton were evaluated.

The mean population of jassid was found lowest in neem leaf extract with $100 \mathrm{ml} \mathrm{L}^{-1}$ water followed by chilli powder@ $20 \mathrm{~g} \mathrm{~L}^{-1}$ water after 24 and 48 hours of spraying when applied of 7 days' interval. But after 72 hours of spraying the mean population of jassid was the lowest in chilli powder treated plot followed by neem leaf extract treated plot. Botanical treatments have an insignificant effect on the population of beneficial insects.

The highest yield was found in neem leaf extract @ 100 $\mathrm{ml} \mathrm{L}^{-1}$ water followed by chilli powder @ $20 \mathrm{~g} \mathrm{~L}^{-1}$ water treated plot when applied of 7 days' interval. Garlic extract@100 g L ${ }^{-1}$ water and neem oil @ 5 ml $\mathrm{L}^{-1}$ water treated plots also gave a good result. The results obtained from the application of black pepper powder, coriander powder, turmeric powder, eucalyptus oil, mahogany oil were also satisfactory and better than that of the control.

\section{Acknowledgement}

RMC of BSMRAU is duly acknowledged for providing fund to carry out the Research.

\section{Reference}

Ali, A. 1992. Physio-chemical factors affecting resistance in cotton against jassid, (Amrasca devastans Dist.) and thrips, (Thrips tabaci Lind.) in Punjab, Pakistan. Ph.D Thesis, Department of
Entomology, Agricultural University, Faisalabad. p. 430.

Amin, M. R.; Ahad, M. A.; Hossain, M. H.; Hossain, S. M. A. and Tithi, D. A. 2008. Characteristics of some cotton varieties in relation to seasonal abundance of pests, predators and their impact on yield and quality. Journal of Agroforestry Environment, 2: 6770 .

BTMA (Bangladesh Textile Mills Association). 2010. An article published on BTMA lauds government decision to stop import of yarn thru' land port, The Independent.

CDB (Cotton Development Board). 2015. A report on Cotton and Products Annual Bangladesh- Gain reports.

Chinniah and Mohanasundaram, M. 1999. Evaluation of neem derivatives for their toxic effect on safety to predatory mites, Amblyseius spp. (Acarina: Phytoseidae) in cotton ecosystem. Pestology, 123: 45-48. cotton aphid (Aphis gossypii). Indian Journal of Agricultural Science, 63: 134-135.

Gowez, K. A. and Gowez, 1984. Statistical procedures in Agricultural Research. New York, $2^{\text {nd }}$ Edition. pp. 680

Kumar, A. R. V. and Sangappa, H. K.. 1989. A note on the performance of plant product in the control of gram caterpillar in Bengal gram. Current Research, 13: 38- 40.

Mandol, M. S. 2008. An article on Status of cotton in bangladesh published in ICAC (International Cotton Advisory Committee) 4th meeting of Asian Cotton Research and Development Network.

Wadud, M. and Moniruzzaman, F. M. 2001. Disease and Pest Management. Agricultural Research in Bangladesh in the 20th Century, BARC, Farm gate, Dhaka. pp. 256 - 264.

Walter, J. F. 1999. Commercial Experience with Neem Products. Humana Press. pp. 155-170. 